 \\ JDss | Journal of Development and Social Sciences WWW.Jdss.org, ,1k \\ RESEARCH PAPER
}

\section{Women Empowerment: A Case of Pakistan}

\section{Tahira Shahzad}

Lecturer, Department of International Relations, University of Sialkot, Sialkot, Punjab, Pakistan

\begin{tabular}{|c|c|}
\hline PAPER INFO & \\
\hline $\begin{array}{l}\text { Received: } \\
\text { January 09, } 2021 \\
\text { Accepted: } \\
\text { March 15, } 2021 \\
\text { Online: } \\
\text { March 31, } 2021\end{array}$ & $\begin{array}{l}\text { Women empowerment has taken a central position on international } \\
\text { forum and it is still a focusing and critical issue. For instance, women } \\
\text { remained under-represented in education and comprise nearly sixty- } \\
\text { seven percent of the world's illiterate persons. Moreover, women are } \\
\text { the major part of the working poor. There are also many areas in }\end{array}$ \\
\hline $\begin{array}{l}\text { Keywords: } \\
\text { Dimensions, } \\
\text { Gender Inequality } \\
\text { Social, Political, } \\
\text { Status, } \\
\text { Women } \\
\text { Empowerment }\end{array}$ & $\begin{array}{l}\text { difference is also seen in the gender's voice in society; as women } \\
\text { opinions are not given a proper consideration. A couple of examples } \\
\text { are seen in different conditions. It has been considered that women } \\
\text { empowerment can resolve this issue of discrimination and will } \\
\text { effectively decrease these differences. Consequently, finding the } \\
\text { reasons that lead to women's empowerment requires more attention. }\end{array}$ \\
\hline $\begin{array}{l}\text { *Corresponding } \\
\text { Author: }\end{array}$ & $\begin{array}{l}\text { Achieving as an objective of women empowerment is a way in right } \\
\text { direction. Empowering women as economic, social and political actors } \\
\text { can change policy options and make organizations more range of } \\
\text { diverse voices on different forums. It is essential for development } \\
\text { process to eliminate gender inequality at both levels i.e. societal and } \\
\text { household matters. Since empowerment is a diverse and } \\
\text { multidimensional concept and it is clear at different spheres e.g. } \\
\text { household and community level, national and international and in } \\
\text { different domains it is seen that is political, social and economic } \\
\text { domain. It is an emerging issue that must be highlighted at community } \\
\text { or individual level and also at national and international platform. It is } \\
\text { obvious that understanding of women empowerment is lacking on all } \\
\text { levels. }\end{array}$ \\
\hline
\end{tabular}

Introduction

Women Empowerment and gender equality debates have grown worldwide over the last three decades. It has been admitted that considering females' involvement unimportant in the making of policies can have adverse effects on development of society. United Nations held an International Conference on Women in Beijing in 1995 with an agenda of bringing women empowerment in society and to abolish gender inequality. The third target of Millennium Development Goal is bringing gender equality and making women empowered. Many states, regions and International Development Organizations have dedicated themselves to lessen gender equality as an indispensible factor for an expandable economic development. Women empowerment works in all the dimensions which include economic, political, cultural, legal, social and psychological (Malhotra et al. 
2002). This explains the concept of women empowerment in a broader perspective. Although, the idea of women empowerment is well- defined but there are some limitations in measuring women empowerment as the society lacks in standardized ways. Everyone has ability to influence others and every human should be equal and it is birth right to be free in expressing their ideas, thoughts and viewpoints. So, if the ideas of women are listened properly and equal status is given on equal basis then it leads to economic competence and other development results in this sphere. Empowering women as economic, social and political actors is not only needed for the progress of a state but also inevitable to promote economic growth and reduce poverty ratio. (Chaudry et al.2012). According to United Nations Women Policy Division (2013), women empowerment is crucial and all the policies development projects need to be made with gender equality. Early marriages are very common in most of the developing countries like Pakistan that gives rise to increasing female unemployment rate. It forces women to be dependent on men as they lack in the tendency to be independent. Early marriage is one of the significant reasons of minimal participation of women in the labor market as compared to the developed nations. A lot of literature asserts that this concept is affiliated with the use of contraceptive and low fertility (Woldemicael, 2009). Moreover, education is the key determinants of women empowerment which improves the economic condition but lowers fertility rate. (Mason, 1987). In the field of politics, women who are educated tend to be empowered because they know about their legal rights and they can dynamically take part in political decision making process (Rihani et al. 2006). It is need of the hour to narrow the gap between male and female. These results can be achieved wile empowering the women. First, it is necessary to understand that how women empowerment is valuable and second, it must be a centre point on the individual and community level particularly in Pakistan. This condition is being criticized because it does not have specific effects at community or individual level. But it has a broader scope of common frameworks at national and international level. (Samman \& Santos, 2009) Consequently, reasons of empowerment are different on different levels depending on situations, consequences on which domain or sphere is going to be investigated. Specifically, development in one domain does not include all domains of progress. The concept of empowerment is largely unexplored on all levels, domain and in all spheres.

In a patriarchal society like Pakistan, women empowerment is very difficult to achieve in countries like Pakistan where patriarchal society does not let women go out of their bounds without the governance of men. It is followed as traditions and cultural norms in the society and no one can surpass it. In Pakistani societies, men are supposed to make all the important and unimportant decisions regardless of the female opinion.

\section{Women Empowerment}

The roots and initial meaning of this concept is discussed in the Protestant Reformation that highlights historic struggle for social justice. Moreover, when movements like feminism and black power struggled for equal status and more development, the idea got more attention in political connotation. Since then the world has sometimes used or misused this concept; as the concept has plenty of definitions which deprived the real meanings of empowerment (Batliwala,2007). One of the reasons is that women empowerment is a complex and critical phenomenon which makes it hard to explain it in a simple and straightforward way. In simple words, empowerment can be said to stand for 
the expansion in freedom of choice and action which means an increasing control over one's resources in return (Narayan, 2002).

The term women empowerment is defined differently in the social, political and economic context. World Bank (2001) defines "the expansion of the freedom of choices and action, which could increase women authority and control over resources and decision regarding their life."Similarly, Through Women empowerment, women become capable to control, take ownership of the decisions and choices they make and also build the strategies of life (Kabeer 2001). However, the idea itself depends on women that how they empower themselves by getting education, learning skills, building capacity and learn to change themselves according to the need of time.

\section{Different Dimensions of Empowerment}

\section{Social Dimension}

Social empowerment covers many areas of the social wellbeing of women like health, female education, equal justice and equal opportunities as men. Primary school education and the women empowerment are correlated with each other in a positive way as the female education reduces the gender differences and gives pace to economic growth. (Kabeer, 2003). The significance of primary education is stressed in the Millennium Development Goals as the second objective. In Pakistan, women primary literacy rate has been improved from 12.5 in 1975 to $39.2 \%$ in 2004 . And it went up to $48 \%$ in 2012-13. Even the women's overall enrollment rate has massively increased to $70 \%$ at the primary level. This improvement further reflected in their increased contribution in the labor market. But on the other hand, women have poor health status that can be seen from the rate of infant mortality, maternal mortality rate and multiple pregnancies. (Measles, Mumps and Rubella) MMR was 230 in 2005,190 in 2010 and 170 in 2013 per 100,000 live births and infant mortality rate was 80 in 2005, 73 in 2010 and 60 in 2013 per 1000 live birth (World Development indicators).whereas the fertility rate is $70 \%$ during the last three decades however it is decreasing. Hence the social factors need to play the key role in improving the health status of women to improve the economic and productive growth of the society

\section{Economic Dimension}

Another aspect of women empowerment is economic empowerment that includes access to finances, low poverty rate, and economic development. In Pakistan the current statics reveal that women are the less privileged gender. This is shown in many ways for example the rate of female labor force in 2003-2004 extremely low due to early marriages, strong cultural and social barriers on outside movement, less opportunities, and burden of household work. After adopted methodology was included in the Labor Force Survey 1990-91 the labor force participation now has 14 specific agricultural and nonagricultural activities. Women have 10\% participation in the formal sector. However their employment rate in the informal sector is much better. In Pakistan, the home-based workers fall below the poverty line and they tend to stay at home and raise their children in both rural and urban areas. In Pakistan the average female participation in the urban sector was around $4.0 \%$ in 1970's and 1980's but it improved in years afterwards, and became $10.8 \%$ in 2013. The unemployment rate in the urban areas is almost $19 \%$. In the rural sector female participation is $67 \%$ which is greater than that of male which is $43 \%$ (UNDP report). Rural 
female participation rate has averaged around $14.5 \%$ to $27.2 \%$ during 1974 to $2012-13$. The current female unemployment rate is $6.8 \%$ that shows that more women want to work in the labor market while the available job opportunities are not adequate.

\section{Political Dimension}

Women's empowerment has been one of the major ideologies in Pakistan's national development policies since the state was coming into being. The Constitution of Pakistan holds no discriminations against women and gives them a full right to participate in the development of the state. (Article 25, 26 and 27 and 32 of Pakistan)

To be empowered, the political rights are crucial to be given and used. The purpose of women empowerment is to enhance the role of women in decision-making. The most fundamental right is the freedom of making decision rather than letting someone else to make it. Like social and economic rights, political rights also hold great importance. In Pakistan the gender gap is visibly seen in the political participation of women. Likewise in most developing countries small number of women is found in the legislative assemblies or other political institutions. Men dominate the political world. It is believed generally that politics demands masculine qualities such as activeness, assertiveness, not feminine characteristics of passiveness and docility; hence women are supposed to remain out of it. Even the house is dominated by patriarchal norms; therefore, women are not supposed to interfere in it. Like community and state levels, they are considered to be ineligible for the leadership of household as well ( Farooq, 2002).

Being political strong has a massive impact on empowerment model as it is a vital part of gender empowerment. The assertive and active participation by any group or class in politics would determine their role and influence in decision-making process that lead to political empowerment.

All three constitutions of Pakistan (1956, 1962 and 1973) gave women right to vote. It was expected that women would be given an opportunity to raise their issues through this right. It was also expecting to bring women into existing political structures. But, women continued to face problems in exercising the right to vote. However, in some tribal and less educated areas of Pakistan, it is a common practice for political parties to mutually agree on not letting their women vote.

\section{Women's Representation}

Another important variable to measure the level of political participation of women is their representation in political parties. To judge the participation of women at the level of political parties and legislatures, it is important to take into account their numbers at the ordinary membership level, the number of tickets given to them, and their representation in decision-making bodies of the political parties. Since independence, women representation is very low in legislative and political bodies (Farooq, 2002).

Political empowerment depends upon the women representation in political process and they will be empowered when $50 \%$ of the seats will be given to women. In all three constitution of Pakistan, women are allowed on reserved seats only. Women became politically strengthened since when the law made it compulsory that the National 
Assembly reserve 60 seats out of its 342 for women. Though, many observers think it inappropriate to assign them a specific number of seats.

The women representation in the National Assembly was $4 \%$ in 1997, as compared to $21 \%$ in 2002 and it is improved up to $22.2 \%$ in $2012-13$. The Senate and National Assembly have 17\% seats reserved for women, while the local government has one third of the total seats.(Article 25,26 and 27 and 32 of constitution of Pakistan 1973)All citizens are equal before law and are responsible for equal protection of law. There shall be no gender discrimination.

According to world economic forum report (2014) Pakistan's ranks 85 th in economic empowerment with 71 women in parliament, 138 women in ministerial position, and females headed the state for 23 years.

\section{Causes of Women's Empowerment}

\section{The Educational Sphere}

Throughout the development literature, education is considered to be the key factors of women's empowerment. Samman and Santos highlighted importance of this topic and find that education has a significant relation with women's empowerment in all studies. For instance, the research shows that an increase in women's literacy rate is correlated with women being able to be independent and can spend money, as well as their freedom to move (Samman \& Santos, 2009). Another research shows that how education can lead to enhance cognitive ability; and affects women's capacity to reflect and act on their own conditions in their lives (Kabeer, 2005). A factor that might distort the effects of education is the quality of the education. Only having access to education does not automatically imply that the level of quality is sufficient to affect the women's sense of selfworth. Moreover, social inequalities might penetrate the school system forcing children from poorer households to attend lower resourced schools, etcetera (Kabeer, 2005). For this reason, one also has to account for the general character of the schools through different quality measurements.

Hence, education can increase women's empowerment by facilitating women with the ability to make decisions. This strengthens their self- esteem and makes them capable of not running their houses only but to deal with service providers and government officials (Kabeer, 2005).

\section{The Economic Sphere}

There are certain prerequisites that need to be incorporated in order to empower women successfully. One of them is that women must have access to resources - both material and economic ones (Charmes \& Wieringa, 2003). There is a large gap between where women and men work and how much they earn, which is visible across all forms of financial activity (The World Bank, 2011). However, it has been shown that these gender inequalities are likely to decline with economic growth (Forsythe et al., 2000).

Aside from decreasing gender inequalities, growth and economic resources can also contribute to women's empowerment in other aspects. For example, Duflo proves that economic development in general positively affects women's empowerment since it reduces the stress of poverty; richer 
House-holds are less likely to have to face life and death choices. These choices usually lead to hurtful consequences for women, and therefore an increase in resources could effectively reduce the vulnerability for these individuals (Duflo, 2012).

\section{Access to Labour Market}

One way for women to increase their economic status is to participate in the labor market. It has been shown that "when women earn an income they can gain both financial independence and a greater sense of agency over their lives" (Dutt et al., 2016). Thus, the effect of access to the labor market is two-fold; it both increases a woman's leeway by giving her financial means, and it provides her with a feeling of agency.

This change in status affects the woman's voice within the household. Her income and assets will increase her bargaining power and thereby increase her influence regarding household choices (The World Bank, 2011; Samman and Santos, 2009; Kabeer, 1997).

However, an increase in salary and labor force participation might not automatically lead to women's empowerment. For one, women are usually found in work places with a more exploitative nature. Therefore, it is vital to not only look at whether or not the women work, but also where they work. For instance, this can be investigated by ratio between female and male income. The ratio would show how the earnings differ between the groups, which would demonstrate if the women where situated in more exploitative work.

\section{The Legal Sphere}

Cueva states that one "of the most important elements enabling female empowerment is an adequate legal and regulatory framework" (Cueva, 2006). This element captures whether or not women's rights are codified in law. It consists of many aspects. To start with, it includes legal protection on violence against women; such as criminalizing rape within marriage (Cueva, 2006). Another factor is women's ability to inherit or obtain property (Pratley, 2016). Yet an additional aspect is the legal gendering of marriage. Both family, labor and social security laws can discriminate against women, which can be extremely disempowering (Al-Sharmani, 2010).

Without a supportive legal framework, women's potential for agency is severely limited. To clarify, the character of the legal sphere can either enable or disable women from achieving agency. One specific way in which this can operate is through land acquisition - a domain where women usually are discriminated. In order for economic empowerment to be nurtured, one needs to address gender-specific causes such as inequalities in ownership of land (Murthy et al., 2008). However, even if there is clear and equal laws in place, the practice of those laws might not be equal to all for example, rich people might get better treatment as a result of corruption. The extent of corruption in a country is a good indicator of how responsive the state is to vulnerable groups. It can manifest itself in different forms. For example, there might be administrative corruption where one can bribe public officials into an advantageous implementation of existing laws (Grootaert, 2005).

\section{The Effects of Women's Empowerment}


In this section, the effects of women's empowerment will be highlighted. In general, focus will be on identifying the areas in which women has had less control or decisionmaking ability, to see if women's empowerment has changed the conditions for these women. This will be done by first discussing the effects of women's empowerment on women's and children's health. Thereafter, women's representation in the political sphere will be addressed.

\section{Women's Reproductive Health and Children's Health}

This section is divided into two broad sections. The first is devoted to women's reproductive health, where emphasis is given on women's right to birth control. The second concerns children's health, and the effect an increase of women's decision-making ability has on different health outcomes.

\section{Reproductive Health}

Reproductive health is a comprehensive concept, which includes the physical, mental and social well-being of individuals (Wang, 2007). Pillai and Gupta clearly define women's reproductive health in the following way:

The term "women's reproductive health" is often associated with a satisfying and safe sex life, capacity to reproduce, and the freedom to decide if, when, and how to do so. Women's reproductive health is determined by the extent of control one has over decisions such as marriage, when and with whom to engage in sexual relations, regulation of fertility by methods which are free from unpleasant or dangerous side effects of contraception, and access to information on the prevention and treatment of reproductive illness and unsafe childbirth (Pillai \& Gupta, 2006). It is believed that women need to be empowered to know about their reproductive illness and to get over it (Pillai \& Gupta, 2006). For example, a study in Zimbabwe showed that women with education and jobs tend to access contraction (Kabeer,2005). Moreover, the general socio-economic environment is vital (Wang, 2007). In this regard, women's empowerment is crucial, it focuses on letting women lead as life of their choice and make decisions on their own (Pillai and Gupta, 2006). Therefore, empowering women can lead to a social movement for reproductive rights. In any case, it is clear that gender equality is positively correlated with the level of personal reproductive rights (Pillai \& Gupta, 2006). Several researchers shared the same views, and they state that empowerment is associated with the use of birth controls (Samman \& Santos, 2009; Schuler \& Hashemi, 1994; Muzaffar, et al, 2018).

Despite this, Wang thinks that the research on women's reproductive health in relation to social-structural variables is inefficient and insufficient (Wang, 2007). 


\section{Children's Health}

When women's decision-making ability strengthens, they tend not only to promote reproductive rights, but they also invest more in children's well-being, compared to men (Batliwala, 2007).

Moreover, it is evident in both relative and absolute terms; women also spend a larger share of their income on their children. Men on the other hand prefer to spend their income on themselves (Charmes \& Wieringa, 2003). The difference is especially evident in children's health outcomes (Pratley, 2016). Accordingly, one would expect that measures of children's well-being are good indicators of whether or not women have control over resources, and therefore, in turn, the effects of women's empowerment.

\section{Conclusion}

The research strongly supports the idea of women empowerment in the social, political and economic aspects. In the present era of globalization, the role of the women is needed to be enhanced to ensure the positive development of country. To attain this purpose, serious efforts need to be made and the areas of health and education need to be focused. A healthy and an educated woman can be highly productive both at home and outside. Education at primary level should be compulsory for all women as the business sector needs women to grow the economy and basic education is inevitable for this. In Pakistan, women are very talented but are totally unaware of their abilities and the opportunities they can get. By getting education they will be able to recognize them and play their part in the development of the state.

Government should make the policies which are equal for both the genders so that women can take part in labor force. Government can do this by using media both print and electronic. Women can be encouraged to come out and show their potential in the field of economics. Microfinance stimulates the success of women. In Pakistan, the Khushali Bank, Kashf, The First Women Bank and Tameer Bank are already providing microfinance facilities particularly to women. If they become more active and improve their outreach they can change the lives of many women across the country who is striving for their independence. Their political representation is also important in their empowerment. 


\section{References}

Al-Sharmani, M. (2010). Legal Reform, Women's Empowerment and Social Change: The Case of Egypt. IDS Bulletin, 41(2), 10-17.

Batliwala, S. (2007). Taking the power out of empowerment-an experiential account. Development in practice, 17(4-5), 557-565.

Cueva Beteta, H. (2006). What is missing in measures of women's empowerment?. Journal of human development, 7(2), 221-241.

Duflo, E. (2012). Women empowerment and economic development. Journal of Economic literature, 50(4), 1051-79.

Dutt, A., Grabe, S., \& Castro, M. (2016). Exploring links between women's business ownership and empowerment among Maasai women in Tanzania. Analyses of Social Issues and Public Policy, 16(1), 363-386.

Forsythe, N., Korzeniewicz, R. P., \& Durrant, V. (2000). Gender inequalities and economic growth: A longitudinal evaluation. Economic Development and Cultural Change, 48(3), 573-617.

Grootaert, C. (2005). Assessing empowerment at the national level in Eastern Europe and Central Asia. Measuring empowerment: Cross-disciplinary perspectives, 309-40.

Hausmann, R., Tyson, L. D. A., \& Zahidi, S. (2012, August). The global gender gap report 2012. Geneva: World Economic Forum.Jejeebhoy, S. J. (1995). Women's education, autonomy, and reproductive behaviour: Experience from developing countries. OUP Catalogue.

Kabeer, N. (1999). The conditions and consequences of choice: reflections on the measurement of women's empowerment (Vol. 108, pp. 1-58). Geneva: UNRISD.

Malhotra, A., Schuler, S. R., \& Boender, C. (2002, June). Measuring women's empowerment as a variable in international development. In background paper prepared for the World Bank Workshop on Poverty and Gender: New Perspectives (Vol. 28).

Malik, S., \& Courtney, K. (2011). Higher education and women's empowerment in Pakistan. Gender and Education, 23(1), 29-45.

Mason, K. O. (1987, September). The impact of women's social position on fertility in developing countries. In Sociological forum (Vol. 2, No. 4, pp. 718-745). Kluwer Academic Publishers.

Mujahid, N., Ali, M., Noman, M., \& Begum, A. (2015). Dimensions of women empowerment: A case study of Pakistan. Dimensions, 6(1), 37-45.

Murthy, R. K., Sagayam, J., Rengalakshmi, \& Nair, S. (2008). Gender, efficiency, poverty reduction, and empowerment: reflections from an agriculture and credit programme in Tamil Nadu, India. Gender \& Development, 16(1), 101-116. 
Muzaffar, M. Yaseen, Z \& Ahmad, A. (2018). Child Marriages in Pakistan: Causes and Consequences, Journal of Indian Studies, 4(2), 195-207.

Narayan, D., Stern, N., Nankani, G., Page, J., \& Jorgensen, S. (2002). Empowerment and poverty reduction; a source book, the world bank. PREM Washington, DC Google Scholar.

Pillai, V. K., \& Gupta, R. (2006). Cross-national analysis of a model of reproductive health in developing countries. Social Science Research, 35(1), 210-227.

Pratley, P., \& Sandberg, J. F. (2018). Refining the conceptualization and measurement of women's empowerment in Sub-Saharan Africa using data from the 2013 Nigerian demographic and health survey. Social Indicators Research, 140(2), 777-793.

Roberts, A. (2015). The Political Economy of "Transnational Business Feminism" problematizing the corporate-led gender equality agenda. International feminist journal of politics, 17(2), 209-231.

Samman, E., \& Santos, M. E. (2009). Agency and Empowerment: A review of concepts, indicators and empirical evidence.

Schuler, S. R., \& Hashemi, S. M. (1994). Credit programs, women's empowerment, and contraceptive use in rural Bangladesh. Studies in family planning, 65-76.

Wang, G. Z. (2007). Testing the impact of gender equality on reproductive health: An analysis of developing countries. The Social Science Journal, 44(3), 507-524.

U. N. O. (2011). United nations entity for gender equality and the empowerment of women. Balancing the Scales: Groundbreaking Legal Cases that have Changed Women's Lives, 2012. 